\title{
PENGEMBANGAN DESAIN ZONA TAMAN BERMAIN PAUD BAITHANI TENGGER DI DESA TUTUR, NONGKOJAJAR - PASURUAN SEBAGAI KEGIATAN SERVICE LEARNING MATA KULIAH ARSITEKTUR ANAK
}

\author{
Christine Wonoseputro \\ Program Studi Arsitektur, Fakultas Teknik Sipil dan Perencanaan, Universitas Kristen Petra \\ Jl. Siwalankerto 121-131, Surabaya 60236 \\ *Korespondensi penulis, email: christie@petra.ac.id
}

\begin{abstract}
Abstrak: Service Learning yang menjadi implementasi dalam metode mata kuliah Arsitektur Anak dibagi menjadi 3 tahapan pembelajaran yaitu tahapan pendalaman teori tentang perkembangan anak dan arsitektur, eksplorasi taman publik, serta kegiatan live in di Desa Tutur yang menjadi aplikasi nyata dari pembelajaran dengan metode Service Learning itu sendiri. Dalam kegiatan ini, mahasiswa bukan hanya sekedar memberikan pelayanan masyarakat, namun mencoba untuk menganalisa dan memahami masalah sosial apa yang dihadapi oleh masyarakat serta mengangkat problem tersebut ke dalam permasalahan desain lalu memberikan gagasan untuk pemecahan masalah sebagai wujud kemitraan dalam kegiatan Service Learning di PAUD Bethani Tengger di Desa Tutur, Nongkojajar.
\end{abstract}

Kata kunci: Multi intelenjensia, metode Service Learning, kegiatan akademis, Arsitektur anak, PAUD Baithani Tengger, dan aspek pembelajaran.

\begin{abstract}
Service Learning activities has been implemented as Children's Architecture subject teaching methods, which has been devided into 3 learning steps: theory development, public space exploration, and live in activity at Tutur Village, Nongkojajar Pasuruan as the application of it. In the process of learning, students do not only serve public services to the society, but they try to understand and analyse the real social problem that being faced by the society. Students will learn solving the problem and giving suggestion to them as a statement of partnership in PAUD Baithani Tengger in Tutur Village, Nongkojajar Service Learning activity.
\end{abstract}

Keywords: Multiple intelegence, service learning methods, academic program, Children's architecture, PAUD Baithani Tengger and learning aspect.

\section{PENDAHULUAN}

Kegiatan akademis dengan muatan Service Learning (SL) merupakan beban wajib yang harus diampu oleh setiap mahasiswa program studi arsitektur mulai angkatan 2010. Berdasarkan pengalaman-pengalaman pelaksanaan metode SL pada semester-semester yang telah lampau, maka khusus untuk kegiatan dengan metode SL di program Studi Arsitektur perlu untuk secara berkesinambungan dilakukan adanya inovasi dan evaluasi yang berjalan secara berkesinambungan, khususnya dalam hal mengenalkan metode belajar mengajar di dalam, pada, serta melalui masyarakat. Melalui penjabaran yang lebih detail kepada pembelajar, yakni mahasiswa, maka harapannya kegiatan ini akan semakin menarik minat mahasiswa untuk ikut berperan serta aktif, bukan hanya sekedar sebagai sebuah kegiatan untuk mencari nilai semata.

Menurut Wonoseputro (2013, p. 30), dengan belajar secara nyata pada kehidupan masyarakat, diharapkan seorang mahasiswa mampu belajar bukan hanya searah, melainkan dua arah, dengan memberikan aksi-reaksi terhadap fenomena yang terjadi di dalam realita kehidupan yang sesungguhnya.

Dalam penerapan metode SL di mata kuliah Arsitektur Anak, menurut Wonoseputro, SL yang diharapkan bukan hanya sekedar menerapkan SERVICE-learning atau service-LEARNING, melainkan usaha RKBM menyeimbangkan antara SERVICE dan LEARNING sehingga diharapkan pelaksanaan metode SL dimana SERVICELEARNING yang ideal dapat dicapai dengan maksimal. Setelah 4 semester berturut-turut ber- 
usaha untuk melaksanakan metode SL dengan ideal maka, berdasarkan atas hasil evaluasi mata kuliah secara berturut-turut kegiatan SL untuk mata kuliah KKP Arsitektur Anak dibagi menjadi 3 tahapan:

1. Tahap pendalaman teori

2. Tahap eksplorasi lapangan

3. Tahap Live In/Pelaksanaan lapangan, dimana kegiatan implementasi teori dalam praktek di masyarakat yang sesungguhnya dilaksanakan. (Wonoseputro, 2013, p. 3-11).

PENJABARAN METODE SL PADA MATA KULIAH ARSITEKTUR ANAK SEBAGAI WUJUD APLIKASI TEORI-PRAKTEK DALAM PROSES PEMBELAJARAN

Mata kuliah Arsitektur Anak merupakan mata kuliah pilihan dalam alur mata kuliah Kuliah Kerja Pelayanan (KKP), dengan pelaksanaan pembebanan 3 sks pada mahasiswa, dan ditempuh pada semester 6 (dari total 8 semester) pada alir kurikulum Program Studi Arsitektur S1 Universitas Kristen Petra. (Day, Christopher, 2007, p. 105-230). Tujuan pembelajaran pada mata kuliah Arsitektur Anak adalah mahasiswa mampu mengaplikasikan pengetahuan untuk mendesain bangunan yang ramah dan layak anak-anak, sesuai dengan pedoman-pedoman serta kebijakan, untuk mendukung materi dalam tugas-tugas di studio perancangannya serta substansi topik perancangan yang dipilih untuk proyek akhir di program studi arsitektur. Dalam penyusunan kerangka Rencana Kegiatan Belajar Mengajar, topik 12 kali pertemuan dalam perkuliahan membahas pokokpokok Arsitektur anak, yang terbagi atas beberapa metode pembelajaran antara lain:

Perkuliahan, dengan materi 5 topik teori Arsitektur Anak yang dibagi dalam 5 pertemuan, meliputi:

- Pengenalan teori perkembangan anak

- Teori belajar sambil bermain

- Arsitektur dan Lingkungan sebagai ruang belajar pasif (silent lesson)

- Arsitektur ramah anak

- Aplikasi kebijakan "Kota Layak Anak"

Dan materi pelengkap pendukung, yaitu pengantar SL setelah menyelesaikan kelima topik di atas.

Ekplorasi dan diskusi kelompok ruang bermain anak dalam 3 kali tatap muka.
Kegiatan lapangan atau SL itu sendiri, dalam wujud mengambil kasus lapangan dari masyarakat, menganalisa, kemudian mencoba untuk menerapkan gagasan konseptual sebagai bagian dari problem solving atas masalah yang mereka temukan di lapangan yang dilakukan selama 3 hari hidup belajar bersama dengan masyarakat. Pada tahapan ini mahasiswa belajar untuk berdiskusi, mempresentasikan gagasan serta meyakinkan masyarakat atas gagasan yang telah dibuatnya, belajar sekaligus "mengajar" dan mendampingi masyarakat pada saat kegiatan dilaksanakan, serta mendengar masukan-masukan dan saran dari masyarakat sebagai bagian yang harus dipertimbangkan dalam melaksanakan gagasan konseptual yang dibuat oleh mahasiswa. Bagian ini menjadi pengganti "laboratorium" pembelajaran, dimana mahasiswa melakukan tes atau pengujian-pengujian terhadap gagasan-gagasan desain yang biasanya dibuat di dalam studio atau dalam bentuk tugas.

Evaluasi pembelajaran, meliputi penyusunan laporan tertulis, dokumen perancangan konseptual, serta refleksi kegiatan SL sebagai hasil evaluasi dari seluruh rangkaian pembelajaran.

Kegiatan ini masih dilanjutkan dengan kunjungan atau supervisi lapangan Post-Service Learning, di mana dosen Pembina bersama dengan relawan dari mahasiswa dan mitra SL mengadakan kegiatan kunjungan lapangan untuk memantau bagaimana masyarakat kemudian melanjutkan hasil kegiatan SL tersebut secara mandiri namun tetap mendapatkan pendampingan, sehingga kelak seluruh konsep dari kegiatan ini dapat terselesaikan dengan baik. Hal ini dilakukan kurang lebih setelah sebulan tim meninggalkan warga untuk meneruskan pekerjaan tersebut secara mandiri, dengan bantuan dan supervisi dari Tim mata kuliah KKP Arsitektur Anak.

Dalam rangka menyempurnakan pelaksanaan metode SL pada mata kulaih Arsitektur Anak, maka kegiatan disusun dalam kerangka induk jangka panjang. Adapun aplikasi metode SL dalam Rencana Kegiatan Belajar Mengajar pada mata kuliah KKP Arsitektur Anak disusun dalam kerangka rencana jangka panjang dengan detail sebagai berikut: 
Tabel. 1. Penjabaran Rencana Kegiatan SL 5 semester Mata Kuliah Arsitektur Anak ( 2013 - 2016 )

\begin{tabular}{|c|c|c|c|c|}
\hline NO & $\begin{array}{c}\text { SUBYEK } \\
\text { KEGIATAN }\end{array}$ & $\begin{array}{l}\text { POKOK BAHASAN } \\
\text { ARSITEKTUR ANAK }\end{array}$ & KEGIATAN SL & ASPEK PEMBELAJARAN \\
\hline 1 & $\begin{array}{l}\text { Perancangan- } \\
\text { Rencana } \\
\text { Induk TK } \\
\text { dan SD } \\
\text { Baithani } \\
\text { Tengger - }\end{array}$ & $\begin{array}{l}\text { Teori dasar } \\
\text { perkembangan anak } \\
\text { dan } \\
\text { implementasinya } \\
\text { dalam desain } \\
\text { Teori "arsitektur dan } \\
\text { ruang sebagai "silent } \\
\text { lesson"bagi anak } \\
\text { Perancangan } \\
\text { Arsitektur }\end{array}$ & $\begin{array}{l}\text { - Tahap pendalaman teori } \\
\text { - Tahap eksplorasi lapangan } \\
\text { - Live In bersama dengan } \\
\text { warga Baithani Tengger } \\
\text { untuk membuat mock up } \\
\text { desain }\end{array}$ & $\begin{array}{ll}\text { - } & \text { Perancangan Arsitektur } \\
\text { - } & \text { Wawasan material } \\
\text { - } & \text { Penyajian Arsitektur } \\
\text { - } & \text { Aspek teknis bangunan ( prinsip konstruksi } \\
& \text { dan iklim ) } \\
\text { - } & \text { Perancangan berkesinambungan } \\
\text { - } & \text { Komposisi desain } \\
\text { - } & \text { Kerjasama Tim } \\
\text { - } & \text { Ketrampilan konstruksi sederhana } \\
\text { - } & \text { Kerjasama Tim } \\
\text { - } & \text { Komunikasi } \\
\text { - } & \text { Manajemen waktu } \\
\text { - } & \text { Manajemen keuangan } \\
\text { - } & \text { Pelatihan afeksi dan nilai }\end{array}$ \\
\hline 2 & $\begin{array}{l}\text { Pengembang- } \\
\text { an Zoning } \\
\text { Taman } \\
\text { Bermain } \\
\text { PAUD } \\
\text { Baithani } \\
\text { Tengger }\end{array}$ & $\begin{array}{l}\text { Teori "arsitektur dan } \\
\text { ruang sebagai aspek } \\
\text { silent lesson" bagi } \\
\text { anak } \\
\text { Teori Ruang } \\
\text { terstruktur dan } \\
\text { tidak terstruktur } \\
\text { Implementasi Teori } \\
\text { "The Invisible } \\
\text { Playground" dalam } \\
\text { perancangan } \\
\text { arsitektur }\end{array}$ & $\begin{array}{l}\text { - Tahap pendalaman teori } \\
\text { - Tahap eksplorasi lapangan } \\
\text { - Live In bersama dengan } \\
\text { warga Baithani Tengger }\end{array}$ & $\begin{array}{ll}\text { - } & \text { Perancangan Arsitektur } \\
\text { - } & \text { Wawasan material } \\
\text { - } & \text { Penyajian Arsitektur } \\
\text { - } & \text { Aspek teknis bangunan } \\
\text { - } & \text { Perancangan berkesinambungan } \\
\text { - } & \text { Komposisi desain } \\
\text { - } & \text { Kerjasama Tim } \\
\text { - } & \text { Ketrampilan konstruksi sederhana } \\
\text { - } & \text { Kerjasama Tim } \\
\text { - } & \text { Komunikasi } \\
\text { - } & \text { Manajemen waktu } \\
\text { - } & \text { Manajemen keuangan } \\
\text { - } & \text { Pelatihan afeksi dan nilai } \\
\end{array}$ \\
\hline 3 & $\begin{array}{l}\text { Pengembang- } \\
\text {-an zona } \\
\text { edukasi } \\
\text { outdoor } \\
\text { PAUD } \\
\text { Baithani } \\
\text { Tengger } \\
\text { tahap } 1\end{array}$ & $\begin{array}{l}\text { Implementasi Teori } \\
\text { "The Invisible } \\
\text { Playground" dalam } \\
\text { perancangan } \\
\text { arsitektur }\end{array}$ & $\begin{array}{l}\text { - Tahap pendalaman teori } \\
\text { - Tahap eksplorasi lapangan } \\
\text { - Live In bersama dengan } \\
\text { warga Baithani Tengger }\end{array}$ & $\begin{array}{ll}\text { - } & \text { Perancangan Arsitektur } \\
\text { - } & \text { Wawasan material } \\
\text { - } & \text { Penyajian Arsitektur } \\
\text { - } & \text { Aspek teknis bangunan } \\
\text { - } & \text { Komposisi desain } \\
\text { - } & \text { Kerjasama Tim } \\
\text { - } & \text { Kerjasama Tim } \\
\text { - } & \text { Komunikasi } \\
\text { - } & \text { Manajemen waktu } \\
\text { - } & \text { Manajemen keuangan } \\
\text { - } & \text { Pelatihan afeksi dan nilai } \\
\end{array}$ \\
\hline 4 & $\begin{array}{l}\text { Pengembang } \\
\text { an Zona } \\
\text { Edukasi } \\
\text { outdoor } \\
\text { PAUD } \\
\text { Baithani } \\
\text { Tengger } \\
\text { Tahap } 2\end{array}$ & & $\begin{array}{l}\text { - Tahap pendalaman teori } \\
\text { - Tahap survei lapangan } \\
\text { - Diskusi } \\
\text { - Pelaksanaan Perancangan } \\
\text { Lapangan }\end{array}$ & $\begin{array}{ll}\text { - } & \text { Perancangan Arsitektur } \\
\text { - } & \text { Wawasan material } \\
\text { - } & \text { Penyajian Arsitektur } \\
\text { - } & \text { Aspek teknis bangunan } \\
\text { - } & \text { Komposisi desain } \\
\text { - } & \text { Kerjasama Tim } \\
\text { - } & \text { Kerjasama Tim } \\
\text { - } & \text { Komunikasi } \\
\text { - } & \text { Manajemen waktu } \\
\text { - } & \text { Manajemen keuangan } \\
\text { - } & \text { Pelatihan afeksi dan nilai }\end{array}$ \\
\hline 5 & $\begin{array}{l}\text { Pengembang } \\
\text { an Zona } \\
\text { Edukasi } \\
\text { indoor } \\
\text { PAUD } \\
\text { Baithani } \\
\text { Tengger } \\
\text { Tahap } 3\end{array}$ & & $\begin{array}{l}\text { - Tahap pendalaman teori } \\
\text { - Tahap survei lapangan } \\
\text { - Diskusi } \\
\text { - Pelaksanaan Perancangan } \\
\text { Lapangan }\end{array}$ & $\begin{array}{l}\text { - Perancangan Arsitektur } \\
\text { - Wawasan material } \\
\text { - Penyajian Arsitektur } \\
\text { - Aspek teknis bangunan } \\
\text { - Komposisi desain } \\
\text { - Komunikasi } \\
\text { - Kerjasama Tim } \\
\text { - Pelatihan afeksi dan nilai }\end{array}$ \\
\hline
\end{tabular}




\section{PROFIL PAUD BAITHANI NONGKOJAJAR SEBAGAI MITRA KEGIATAN SL MATA KULIAH ARSITEKTUR ANAK}

PAUD Baithani merupakan bagian dari kompleks sekolah Kristen Baithani Nongkojajar, PAUD ini merupakan fasilitas pengembangan sekolah yang paling baru yang dimiliki oleh yayasan Baithani Tengger sebagai wujud pengembangan misi pelayanan pendidikan bagi kawasan Nongkojajar dan sekitarnya.

Sebagai konsistensi komitmen yayasan bagi penyelenggaraan dan aksesibilitas pendidikan bagi kawasan ini, saat ini PAUD menampung 20 orang anak, dimana anak-anak tersebut bebas USPP.

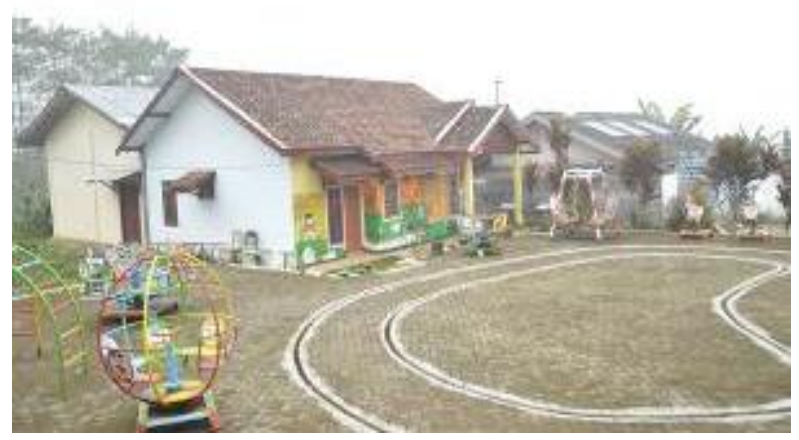

Gambar 1. Kondisi Eksisting PAUD

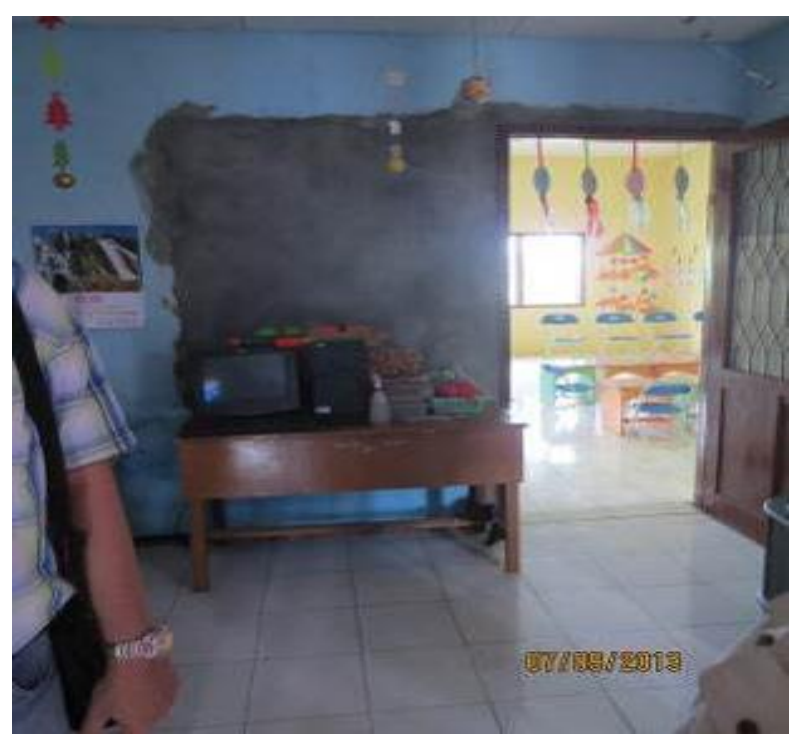

Gambaar 2. Kondisi Eksisting Kelas

Menurut data survei yang dilaksanakan di awal bulan September 2013 (tanggal 7 September 2013), kondisi fisik PAUD masih membutuhkan perencanaan yang lebih baik. Dinding terlihat dicat apa adanya, dengan finishing dinding yang bersifat tambal sulam. Kelas juga belum dirancang dengan desain dengan baik sehingga perabot, bahan ajar dan alat bermain banyak yang tercecer. Masalah lain yang juga ditemukan di lapangan adalah belum adanya perancangan induk untuk layout kelas dan ruang yang lain, yang dikarenakan penggunaan PAUD ini sendiri adalah hasil alih fungsi dari rumah tinggal yang belum pernah ditransformasikan dalam perancangan arsitektural untuk menjadi sebuah sekolah.

\section{Masalah Perancangan}

Kondisi yang dikeluhkan oleh warga PAUD Baithani adalah kesulitan mendapatkan murid baru, sampai guru-gurupun harus berjuang dari rumah ke rumah untuk mendapatkan murid yang akan diajar. Hal ini dikarenakan kondisi sekolah adalah minoritas di tengah mayoritas penduduk. Di sisi lain, kesetiaan para guru juga perlu mendapat apresiasi. Dengan fasilitas sekolah yang terbatas dan apa adanya, para guru masih setia dan memiliki beban untuk tetap setia mengajar.

Untuk membantu menyelesaikan masalah PAUD, maka tim KKP Arsitektur Anak mengajukan konsep perbaikan dan pembenahan fasilitas sehingga sekolah memiliki nilai tambah untuk menjaring pendaftaran siswa baru.

Berdasarkan analisa lapangan, maka tim mengajukan rencana pengembangan fasilitas taman bermain sebagai fasilitas plus yang akan dimiliki sekolah. Melalui pengembangan dan penataan zoning taman bermain, dimana di dalamnya terdapat taman edukasi flora dan fauna, taman lalu lintas, dan taman bermain anak-anak (playground) diharapkan fasilitas ini mampu menarik minat calon orang tua murid di sekitar desa Tutur untuk menyekolahkan putra putrinya kelak.

\section{PELAKSANAAN RENCANA KEGIATAN BELAJAR MENGAJAR KKP ARSITEKTUR ANAK SEMESTER GENAP 2013-2014}

\section{Pemahaman Teori Arsitektur dan Ruang untuk Anak}

Menurut anak pada usia Golden Age merupakan usia yang paling kritis dalam tahapan kehidupan manusia untuk bertumbuh dan berkembang. Pada usia tersebut stimulus baik yang bersifat aktif maupun pasif harus dengan maksimal dilakukan, supaya anak dapat melalui tahapan perkembangan berikutnya, yaitu masuk tahapan usia sekolah, dengan baik sebagaimana dinyatakan oleh Piaget dalam Elkind (1976). Piaget meyakini bahwa seorang anak dapat membangun sendiri kecerdasan kognisinya. Piaget meyakini bahwa setiap manusia atau individu akan cenderung menyusun pengeta- 
huan kecerdasannya berdasarkan 2 proses mendasar yaitu pengorganisasian dan proses adaptasi. Pengorganisasian adalah sebuah proses penyusunan sistem-sistem yang koheren berdasarkan atas stimulus yang diterima oleh individu tersebut, sedangkan proses adaptasi adalah sebuah proses atau kemampuan bawaan yang dimiliki olehs etiap individu atau organisme untuk beradaptasi dengan lingkungan sekitarnya.

Piaget juga meyakini bahwa dalam penyusunan kecerdasan manusia, kedua proses mendasar tersebut akan melibatkan faktor fisik (fisik biologis, keberadaan manusia dan kondisi lahiriah manusia tersebut) dan faktor lingkungan di sekitar manusia.

Day dalam Environment and Children: Passive Lessons from the Everyday Environment, mengungkapkan bahwa lingkungan akan berfungsi sebagai "Silent Lesson", khususnya bagi anak-anak di usia 3-5 tahun, dimana pada rentang usia tersebut seorang anak akan secara optimal belajar melalui pengamatan lingkungan di sekitarnya atau banyak belajar melalui aspek visual (Day, 2007, p. 115).

Hal ini selaras dengan Dudek (2005, p. 31) yang menegaskan beberapa kasus yang dipaparkan melalui Children's Space, bahwa hubungan timbal balik antara anak-anak dan arsitektur maupun ruang dalam arsitektur akan saling menunjukan ketergantungan serta hubungan aksi reaksi antara manusia sebagai pengguna dan ruang itu sendiri.

Melalui pemahaman beberapa teori seperti yang diungkapkan di atas, dan pemahaman akan teori ruang yang dicetuskan oleh Tschumi (1995) dalam The Event Space maka Wonoseputro (2007) menyatakan dalam studinya tentang Children's Learning Space as The Invisible Playground bahwa ada 5 aspek ruang yang akan mencetuskan dan mendukung kegiatan "belajar adalah bermain" bagi anak, yaitu:

1. Adanya elemen kejutan

2. Adanya aspek interaksi dan timbal balik atara obyek dan pengamat (anak)

3. Adanya rasa aman

4. Adanya kesempatan

5. Adanya aspek pengawasan oleh orang yang lebih dewasa

\section{Pemahaman SL sebagai metode pembelajaran di mata kuliah Arsitektur Anak}

Pada mata kuliah Arsitektur Anak, tahapan pemahaman akan metode SL itu sendiri diberikan sebagai landasan untuk melakukan rencana kegiatan dan evaluasi setelah mereka melakukan seluruh rangkaian kegiatan di akhir semester. Selaras dengan yang diungkapkan Widianingsih dan Barliana (p. 1-5) bahwa pendekatan partisipatif dalam perancangan arsitektur, dalam hal ini dipahami bahwa metode SL sendiri adalah bagian dari sebuah metode desain partisipatif, dimana mengikut sertakan komunitas sebagai bagian yang utuh dari proses pembelajaran yang akademis, dengan harapan bahwa melalui metode tersebut kedua belah pihak saling diuntungkan dan memperoleh manfaat untuk proses pembelajaran yang berkesinambungan sesuai dengan konsep SL yang telah dijelaskan pada bagian pendahuluan, sehingga antara SERVICE dan LEARNING keduanya mendapatkan porsi dalam materi pembelajaran yang seimbang.

Dalam mata kuliah juga dijelaskan bahwa kemitraan yang bersifat jangka panjang serta penyusunan skenario Satuan Pembelajaran yang bersifat jangka panjang dan estafet setiap semester, maka implikasi kegiatan akan dapat dirasakan secara lebih nyata oleh masyarakat. Yang harus digarisbawahi di sini adalah selaras dengan pernyataan Howard dalam Maybeth dan Barbara (2005, p. 29-33), bahwa untuk kepentingan akademik poin utama tetap adalah "pembelajaran" sehingga tujuan pembelajaran juga harus jelas.

\section{Tahap Eksplorasi Lapangan}

Sebagaimana pada umumnya ritus pembelajaran pada disiplin perancangan arsitektur, sebagaimana diungkapkan Marlinda, Barliana, dan Krisnanto (p. 2-4) bahwa arsitektur perlu membuat, mengalami (dalam hal ini mengalami taman sebagai tempat bermain anak), menggunakan, dan memahami arsitektur sebagai upaya mencapai kreativitas desain, maka pada tahap ekplorasi lapangan, mahasiswa diminta untuk melakukan observasi pada ruang terbuka publik yang ada di kota Surabaya, meliputi 5 taman publik yang memiliki fasilitas bermain untuk anak yang terdaftar dalam situs web Dinas Pertamanan Kota Surabaya, yang terpilih meliputi:

- Taman Bungkul

- Taman Buah Undaan

- Taman Flora

- Taman Sulawesi

- Taman Kalimantan

Melalui tahapan eksplorasi, mahasiswa diharapkan memiliki gambaran umum tentang "perilaku" pengguna taman tersebut, khususnya anak-anak dan orang tua sebagai pengguna dari ruang terbuka kota.

Secara khusus, mahasiswa diminta untuk mengamati dan mencermati elemen fisik taman, men- 
catat suasana taman serta sikon pengamatan. Mereka juga diminta untuk melakukan wawancara dan mendokumentasi kegiatan dalam bentuk foto serta rekaman video sebagai data untuk dapat dijadikan materi diskusi dalam kelas sebagai materi dasar persiapan kegiatan yang akan dirancang untuk "Live In" di desa pada tahapan berikutnya.

\section{Tahap Live In di Desa Tutur, Nongkojajar Sebagai Wujud Aplikasi metode SL di Masya- rakat}

Sebagai wujud dari pelaksanaan metode SL, maka mahasiswa peserta mata kuliah Arsitektur anak melakukan kegiatan live in selama 3 hari berturutturut di Desa Tutur, Nongkojajar untuk belajar bersama dengan warga PAUD Baithani. Dalam kegiatan ini, peserta mata kuliah dibagi menjadi 3 tim meliputi:

- Tim Aksi bersama PAUD

- Tim Pelaksanaan Mural

- Tim Perancangan Taman Bermain

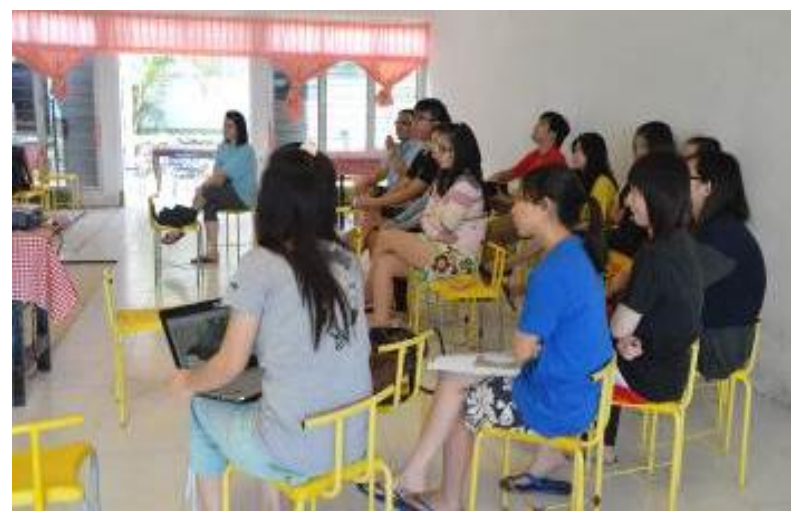

Gambar 4. Suasana Diskusi, Persiapan Kegiatan Lapangan di PAUD Baithani.

Masing-masing tim memiliki lingkup pekerjaan sendiri, dengan dipimpin oleh seorang koordinator tim untuk melaksanakan tugas, mengatur dana, membuat jadwal kegiatan, serta menentukan target kegiatan yang harus dicapai.

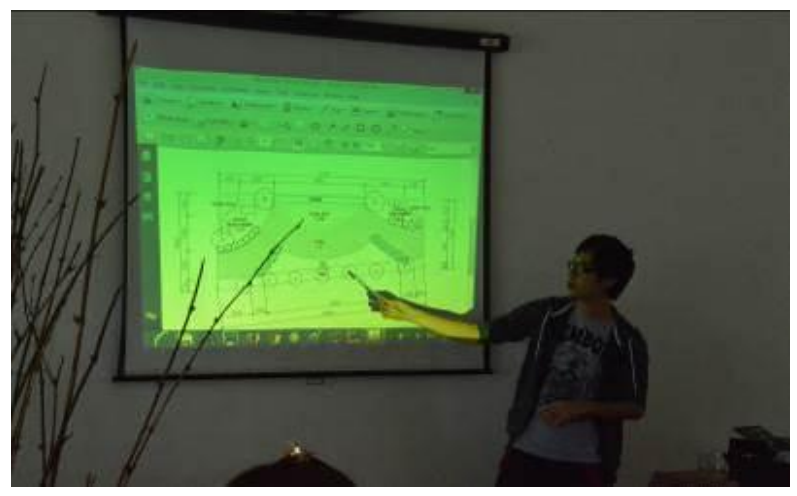

Gambar 5. Jian Honardy Rayawang, mahasiswa peserta KKP Arsitektur Anak sedang mempresentasikan konsep perancangan Taman Bermain pada wakil yayasan Baithani.

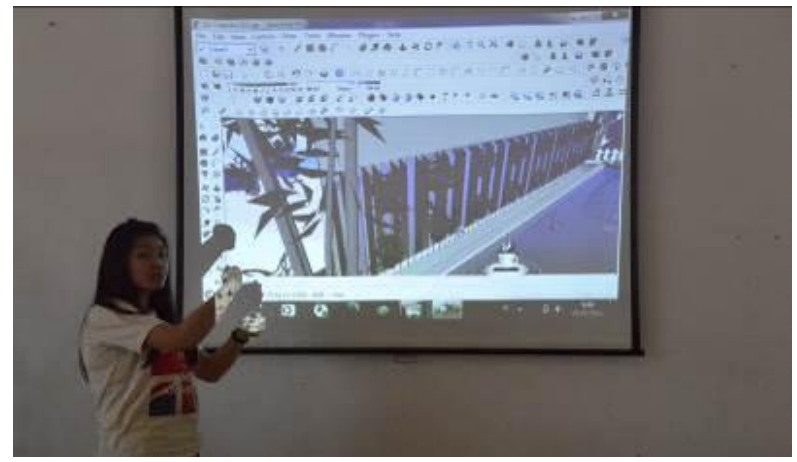

Gambar 6. Ellena Monica, ketua panitia kegiatan Live In memberikan penjelasan detail pelaksanaan pada tim

Tim Aksi bersama PAUD bertugas untuk melakukan kegiatan bermain sambil belajar untuk mengenali karakter anak pada usia 3-6 tahun. Hal ini akan membuat para mahasiswa memiliki kepekaan tersendiri serta menumbuhkan rasa "empati" terhadap anak sebagai pengguna ruang dalam arsitektur. Kegiatan yang dilakukan adalah menyanyi bersama sebagai proses perkenalan pihak asing dalam komunitas anak-anak lalu dilanjutkan dengan belajar bersama berkreasi mengecat pot fantasi, di mana pot tersebut nantinya akan menjadi bagian dari taman edukasi yang dirancang oleh para mahasiswa.

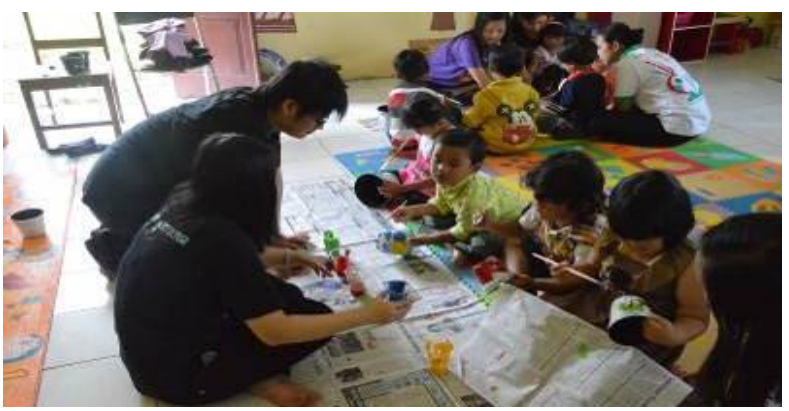

Gambar 7. Tim Aksi bersama PAUD sedang melakukan aktifitas

Tim Pelaksana Mural adalah tim yang menyiapkan elemen taman untuk dipercantik dengan gambar dinding (mural), sehingga dinding bukan hanya sekedar menjadi barrier ruang namun dapat juga menjadi bagian dari desain yang memperkaya kegiatan belajar serta bermain bagi anak-anak.

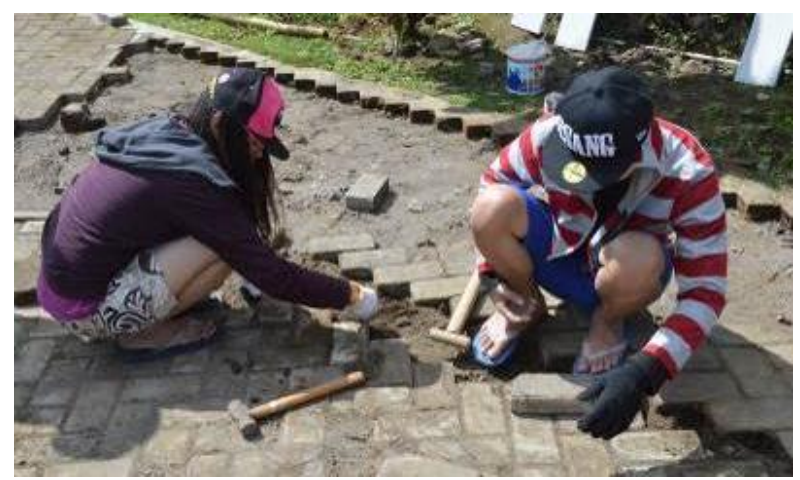

Gambar 8. Kegiatan lapangan 


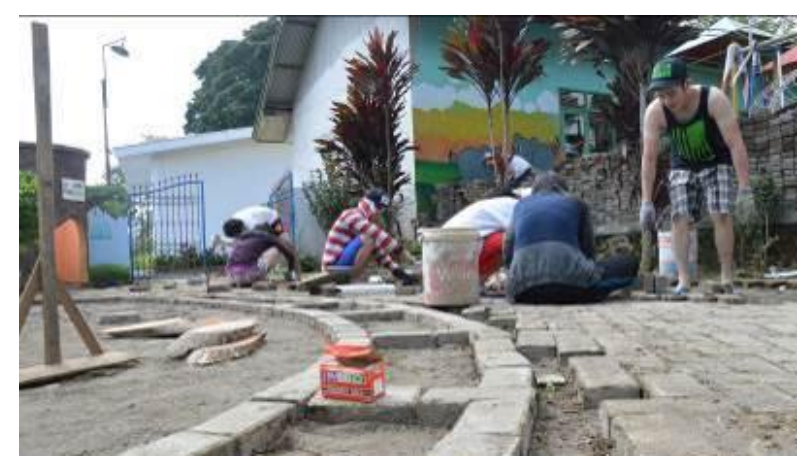

Gambar 9. Aktifitas membongkar paving untuk menyiapkan area taman

Masalah yang dihadapi oleh tim adalah membuat desain dari mural yang akan digambar, sehingga desain tersebut dapat menyatu dengan fasade eksisting dari PAUD, yaitu kisah Nabi Nuh, dimana perahu nabi Nuh dilukiskan mendarat di atas gunung Ararat dan nampak binatang-binatang digambarkan keluar dari bahtera tersebut sehingga anak akan mendapat pembelajaran visual kisah tersebut. Pada bagian detail, mahasiswa mengalihfungsikan elemen-elemen eksisting yang terbengkalai yaitu benteng dan ditransformasi menjadi seperti "batang-batang pohon" di mana di dalamnya dapat difungsikan oleh anak untuk bermain sambil belajar tentang binatang dan tanaman. Walaupun nampaknya seperti kegiatan yang sepele, namun kegiatan bukan hanya sekedar mengecat atau menggambari tembok saja, kegiatan ini membutuhkan sebuah perencanaan dan konsep global, sehingga rancangan yang dihasilkan merupakan satu kesatuan konsep yang utuh.

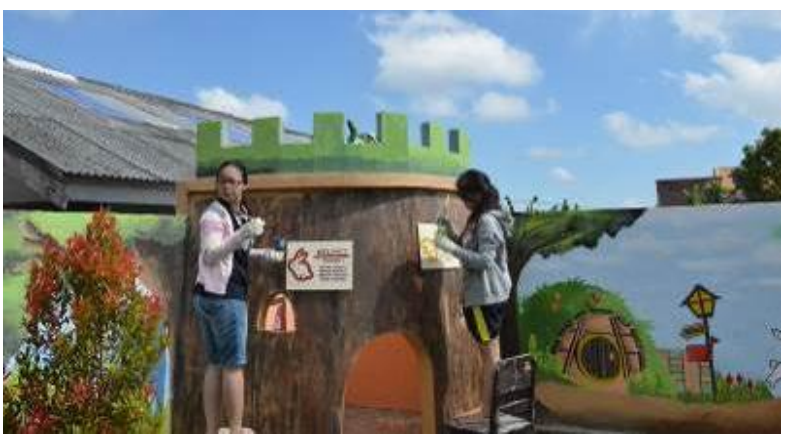

Gambar 10. Tim Mural melakukan pengecatan dinding taman sebagai bagian dari desain.

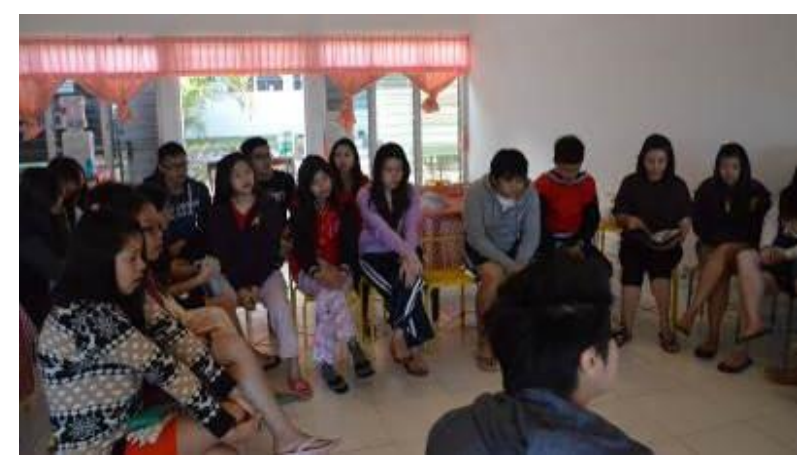

Gambnar 11. Ibadah Pagi

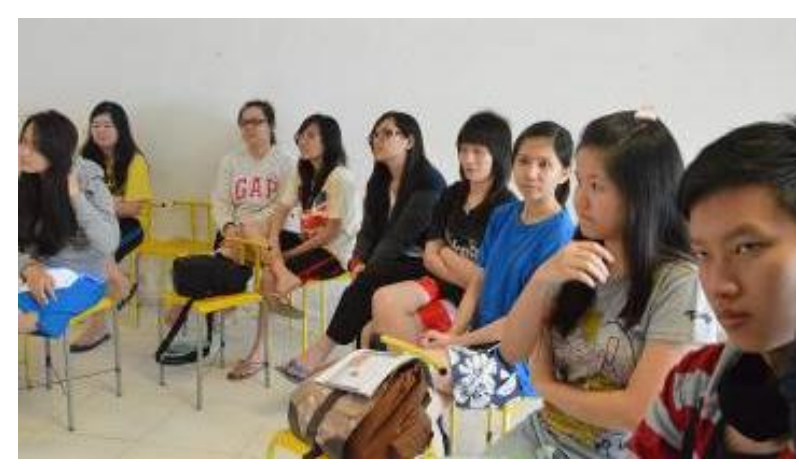

Gambar 12. Diskusi dan evaluasi kegiatan pada sore hari

Tim Perancangan adalah tim yang bertugas membuat konsep perancangan taman bermain secara utuh, dimana tim ini banyak bekerja dengan gambar-gambar perancangan, sehingga berikutnya apabila tim KKP Arsitektur anak telah kembali ke Surabaya, maka warga Baithani dapat secara mandiri meneruskan pekerjaan yang telah dilakukan berdasarkan atas gambar perancangan tersebut. Gambar perancangan yang dihasilkan meliputi:

- Layout Plan

- Gambar-gambar Potongan

- Detail

- Perspektif suasana

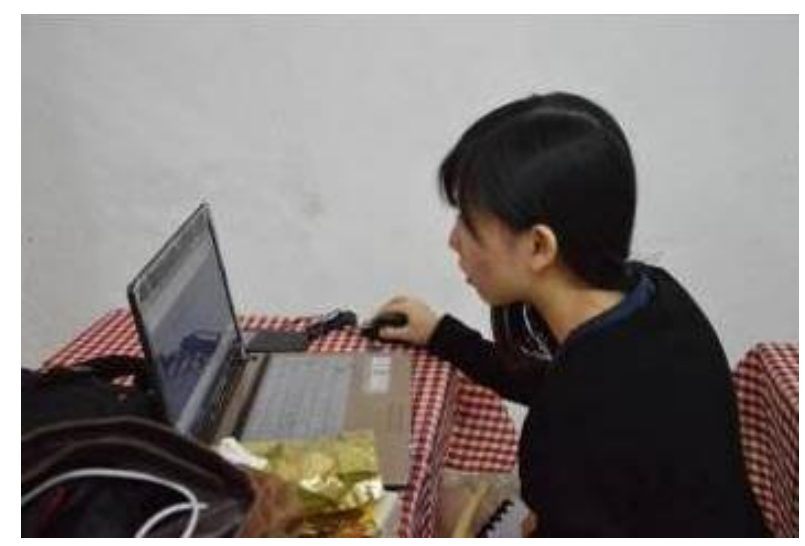

Gambar 13. Tim perancangan menyempurnakan detail gambar

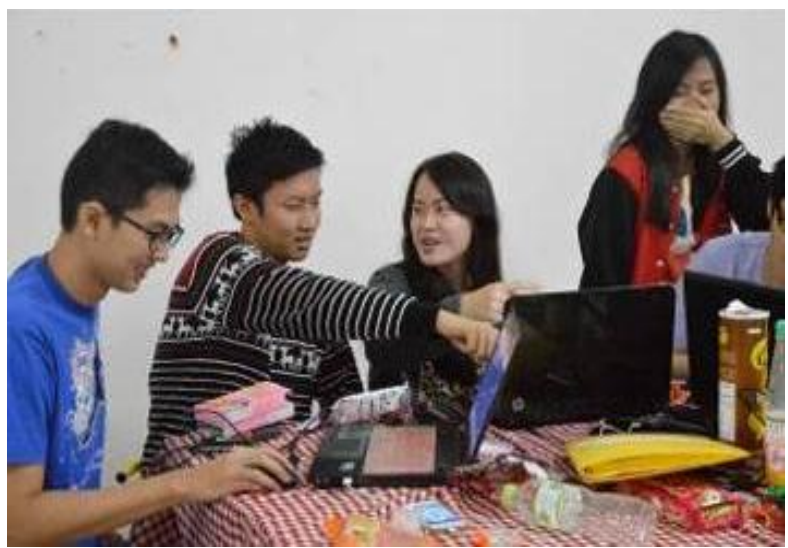

Gambar 14. Para anggota tim perancangan berdiskusi untuk menyempurnakan gambar. 


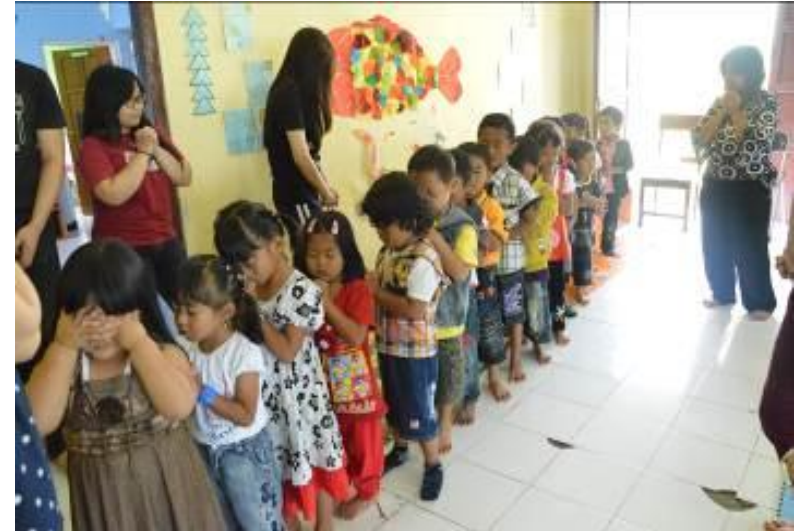

Gambar 15. Mengakhiri kegiatan bersama anak PAUD Baithani dengan doa bersama

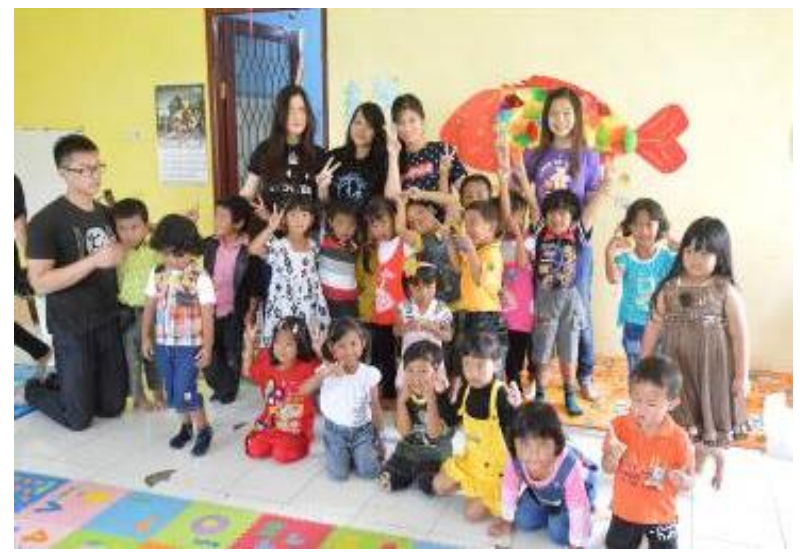

Gambar 16. Foto perpisahan dengan siswa PAUD Baithani

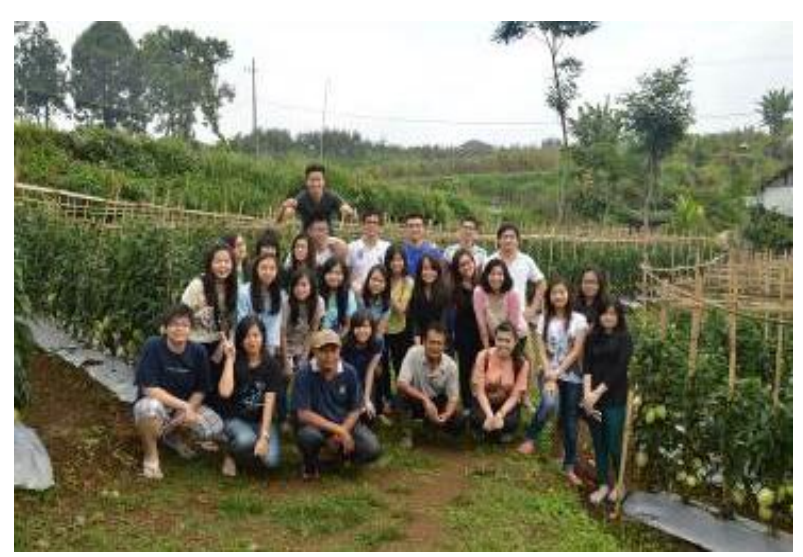

Gambar 17. Segenap anggota tim/peserta mata kuliah KKP Arsitektur anak semester genap 2013/2014 Prodi Arsitektur Universitas Kristen Petra dan dosen pembina berfoto bersama sebelum meninggalkan lokasi Live In.

\section{KESIMPULAN DAN SARAN}

\section{Penjabaran metode SL dalam mata kuliah Arsitektur Anak}

Berdasarkan dari hasil refleksi yang disampaikan oleh mahasiswa peserta matakuliah maupun umpan balik yang didapatkan dari mitra kegiatan SL, maka dalam beberapa hal menonjol kemudian disimpulkan sebagai berikut:

\begin{tabular}{|c|c|c|}
\hline Kegiatan & $\begin{array}{l}\text { Aspek yang } \\
\text { didapat warga } \\
\text { (masyarakat) }\end{array}$ & $\begin{array}{l}\text { Aspek yang } \\
\text { Dipelajari } \\
\text { mahasiswa } \\
\text { Sesuai tujuan } \\
\text { kurikulum } \\
(\text { LEARNING) }\end{array}$ \\
\hline $\begin{array}{l}\text { Aksi bersama } \\
\text { PAUD }\end{array}$ & $\begin{array}{l}\text { Kreatifitas } \\
\text { mengajar dan } \\
\text { kreatifitas kegiatan }\end{array}$ & $\begin{array}{l}\text { - Penguasaan } \\
\text { pengetahuan: } \\
\text { Menguasai teori }\end{array}$ \\
\hline $\begin{array}{l}\text { Membuat } \\
\text { mural dinding }\end{array}$ & $\begin{array}{l}\text { Pengolahan elemen } \\
\text { terabaikan menjadi } \\
\text { elemen yang punya } \\
\text { nilai guna dalam } \\
\text { pendidikan usia } \\
\text { dini. }\end{array}$ & $\begin{array}{l}\text { dan dasar } \\
\text { pengetahuan } \\
\text { tentang kebutuhan } \\
\text { anak dan ruang } \\
\text { bermain anak, } \\
\text { kemampuan }\end{array}$ \\
\hline $\begin{array}{l}\text { Membongkar } \\
\text { paving taman }\end{array}$ & $\begin{array}{l}\text { Mengolah detail } \\
\text { taman menjadi } \\
\text { desain yang lebih } \\
\text { "ramah anak" }\end{array}$ & $\begin{array}{l}\text { mengaplikasikan } \\
\text { teori } \\
\text { perkembangan } \\
\text { anak, termasuk }\end{array}$ \\
\hline $\begin{array}{l}\text { Membuat } \\
\text { mozaik } \\
\text { keramik }\end{array}$ & $\begin{array}{l}\text { Pola lantai yang } \\
\text { inovatif untuk café/ } \\
\text { kantin yang baru }\end{array}$ & $\begin{array}{l}\text { keseluruhan aspek } \\
\text { perancangan } \\
\text { arsitektur (formal } \\
\text { abstrak, sains, }\end{array}$ \\
\hline $\begin{array}{l}\text { Penataan } \\
\text { vegetasi }\end{array}$ & $\begin{array}{l}\text { Warga memperoleh } \\
\text { manfaat melalui } \\
\text { perencanaan taman } \\
\text { toga yang kelak } \\
\text { dapat dipelihara } \\
\text { dan dilanjutkan } \\
\text { secara } \\
\text { berkesinambungan } \\
\text { oleh warga sebagai } \\
\text { fasilitas untuk } \\
\text { penyuluhan } \\
\text { masyarakat dan } \\
\text { kegiatan internal } \\
\text { PAUD itu sendiri. } \\
\end{array}$ & $\begin{array}{l}\text { struktur, dan } \\
\text { referensial), dan } \\
\text { sosial budaya } \\
\text { - Ketrampilan kerja } \\
\text { Melatih ketrampil- } \\
\text { an penyajian } \\
\text { arsitektur dan } \\
\text { ketrampilan } \\
\text { pelaksanaan } \\
\text { lapangan secara } \\
\text { pragmatis. } \\
\text { - Sikap dan tata } \\
\text { nilai } \\
\text { Menghormati }\end{array}$ \\
\hline $\begin{array}{l}\text { Koordinasi } \\
\text { lapangan } \\
\text { dengan warga } \\
\text { Baithani }\end{array}$ & $\begin{array}{l}\text { Warga mendapat } \\
\text { informasi tentang } \\
\text { perkembangan } \\
\text { PAUD di kota besar } \\
\text { seperti Surabaya. }\end{array}$ & $\begin{array}{l}\text { orang lain, } \\
\text { toleransi, saling } \\
\text { membutuhkan, } \\
\text { dan berempati } \\
\text { terhadap orang } \\
\text { lain. } \\
\text { - Tanggung jawab } \\
\text { dan kepemimpin- } \\
\text { an: } \\
\text { Belajar manajerial } \\
\text { kerja kelompok, } \\
\text { keuangan dan } \\
\text { kepemimpinan }\end{array}$ \\
\hline
\end{tabular}

Catatan dan saran ke depan:

1. Secara disadari atau tidak, kegiatan ini telah mampu meninggalkan kesan dan catatan penting dalam setiap benak mahasiswa. Bukan hanya dari sisi akademis, namun juga membekali mahasiswa dengan soft skill, menumbuhkan rasa empati, serta menanamkan nilai positif. Harapan jangka panjang dari kegiatan ini 
adalah menjadi kegiatan yang mampu menginspirasi serta memberikan wawasan baru kepada mahasiswa untuk kelak berkarya sebagai pemimpin-pemimpin masa depan yang lebih peduli dengan kondisi nyata di masyarakat.

2. Kegiatan SL di Sekolah/PAUD Baithani telah mampu meluaskan kemitraan, bahkan mampu membuka peluang mencari mitra lanjutan untuk mendukung keberadaan sekolah gratis ini dan mencarikan dukungan donator baik yang bersifat perorangan maupun lembaga (gereja, komisi pendidikan, dan lembaga donatur). Hal ini kelak akan membantu serta memberi dukungan agar masyarakat yang dibina mampu berswadaya, mandiri secara finansial, serta mampu melebarkan eksistensi serta sayap pelayanannya di masyarakat yang lebih luas.

\section{UCAPAN TERIMA KASIH}

Secara khusus, ucapan terima kasih diberikan kepada segenap pihak yang telah membantu berlangsungnya kegiatan SL, khususnya kepada Bapak Agustinus Suwito, Bapak Yohanes, dan segenap staff pendidik dari Yayasan Sekolah dan PAUD Baithani Tengger yang telah bersedia bermitra dan bertukar pikiran untuk pelaksanaan kegiatan lapangan mata kuliah Arsitektur Anak.

Ucapan terima kasih juga kami haturkan kepada Lembaga Pengabdian Pada Masyarakat (LPPM) Universitas Kristen Petra Surabaya selaku fasilitator, pendanaan kegiatan lapangan melalui hibah internal yang telah kami peroleh selama proses kegiatan ini berlangsung, serta koordinator pelaksana perkuliahan dengan metode SL Universitas Kristen Petra, yaitu Bapak Yohanes Budi Cahyono yang telah banyak memberikan dukungan khususnya serta telah menjadi pendamping bagi mata kuliah Arsitektur Anak untuk dapat terjun dalam kegiatan pelayanan masyarakat. Segala bentuk saran dan kritik yang membangun akan merupakan masukan yang sangat berharga bagi pelaksanaan metode SL dan perkembangan mata kuliah Arsitektur Anak ke depan.

\section{DAFTAR PUSTAKA}

Wonoseputro, Christine (2013). Program Kegiatan Build Up Caring Sebagai Pelatihan Kecerdasan Multi Intelejensia Bagi Mahasiswa, Program Studi Arsitektur Universitas Kristen Petra, SHARE (Journal of Service Learning), edisi ke 1, Universitas Kristen Petra, Surabaya.

Wonoseputro, Christine, Pengembangan Desain Taman Bermain PAUD Baithani di Desa Tutur Nongkojajar, Pasuruan-Jawa Timur, Laporan Kegiatan Service Learning, Program Studi Arsitektur Universitas Kristen Petra, semester genap 2013/2014.

Day, Christopher (2007). Environment for Children, Passive Lessons from The Every Day Environment, Architectural Press, Routledge, London.

Elkind, David (1976). Child Development and Education: A Piagetian Perspective, Oxford University Press, Oxford.

Mark, Dudek, Children's Space, Elsevier, London, 2005.

Tschumi, Bernard (2005). The Events Space, MIT Press, Massachusetts.

Wonoseputro, Christine (2007). Children Learning Space as The Invisible Playground, MASD Thesis, University of Huddersfield, United Kingdom.

Widianingsih, Lilis dan Barliana, M.S., Pendekatan Partisipatif dalam Metode Penelitian Arsitektur, diunduh dari jurnal elektronik http:// file.upi.edu/Direktori/FPTK/JUR._PEND._T EKNIK_ARSITEKTUR.

Neal Maybeth dan Holland, Barbara, Symbiosis: When Service-Learning Meets the Work of Howard Gardner, Growing to Greatness, 2005. Makalah dipublikasikan dan diunduh dari http://www.nylc.org/sites/nylc.org/files/files/ 115SLGardner.pdf.

Marlinda, Elin Sekar Barlianan, M. Syaom, dan Krisnanto E. Hubungan Pengalaman Berarsitektur Dengan Kreatifitas Desain Mahasiswa, diunduh dari jurnal elektronik http:// jurnal.upi.edu/file/01_Elin_Sekar_Marlinda _1-161.pdf. 